\title{
Erratum
}

\section{Spirituality and Religion in Patients with HIV/AIDS}

Sian Cotton, PhD, Christina M. Puchalski, MD, Susan N. Sherman, DPA, Joseph M. Mrus, MD, MSC, Amy H. Peterson, PhD, Judith Feinberg, MD, Kenneth I. Pargament, PhD,

Amy C. Justice, MD, PhD, Anthony C. Leonard, PhD, and Joel Tsevat, MD, MPH

Department of Family medicine and the Institute for the Study of Health, University of Cincinnati Medical Center, Cincinnati, OH, USA.

J Gen Intern Med 24(8):994

DOI: $10.1007 / \mathrm{s} 11606-009-1052-3$

(c) Society of General Internal Medicine 2009

P eported on pS7, Results -Demographic and Clinical

1 Characteristics of Sample:

"There were no significant differences between the patients interviewed twice and patients interviewed only once with respect to demographic, clinical and psychosocial characteristics, except that those who had second interviews were more likely to have a viral load below the limit of detection $(<400$ copies $/ \mathrm{mL})$, to be Caucasian, and to have more health disclosure worries than those who were only assessed at baseline."

Correction (should read):

"There were no significant differences between the patients interviewed twice and patients interviewed only once with respect to demographic, clinical and psychosocial characteristics, except that those who had second interviews were more likely to have a viral load below the limit of detection $(<400$ copies $/ \mathrm{mL}$ ), to be Caucasian, and to have lower health disclosure worries than those who were only assessed at baseline."

The authors regret this error.

Corresponding Author: Sian Cotton, PhD; Department of Family Medicine and the Institute for the Study of Health, University of Cincinnati Medical Center, P.O. Box 670840, Cincinnati, OH 45267-0840, USA

The online version of the original article can be found at: $h t t p: / / d x$.doi. org/10.1111/j.1525-1497.2006.00642.x

Published online June 27, 2009 